\title{
Mitos dan Eksplanasi IImiah Lembayung Senja
}

\author{
Rahmat Rizal \\ STKIP Sebelas April, Sumedang, Indonesia \\ e-mail: rari.upiedu@yahoo.com
}

\begin{abstract}
A Violaceous sky attwilightis a natural phenomenon that occurs at sunset. This phenomenon is characterized by areddish yellow sky appearance. To explain this phenomenon, the community has developed a myth that connects the existence of the occult things such as the decline of the evil ghosts, witchcraft, and the epidemic of the disease. This myth has survived long enough in both sundanesse and Banjarmasin, South Kalimantan. The myth is spread in the community from mouth to mouth and occurs from generation to generation. Development of science and the changing minds of modern society effect myths that are present in society began to be degraded by scientific explanations reinforced by empirical evidences. The explanation used in explaining the twilight phenomenon uses the HempelOppenheim explanation model. The explanationsare considered as general statementsconsidered correct. The Violaceous sky at twilight does not indicate the presence of ghosts, witches, or epidemics but it can be explained by Rayleigh scattering theory. The white light from the sun is dissipated by the atmospheric particles into the monochromatic spectrum. As a result of longer stages, the scattered spectrum has the longest wavelength.
\end{abstract}

Keyword: Violaceous sky, myth in the community, scientific explanation, Rayleigh scattering theory

\section{Pendahuluan}

Alam merupakan karunia ciptaan Tuhan yang luar biasa. Semua keteraturan yang tampak di setiap harinya memberikan manfaat yang luar bisa bagi semua mahluk. Salah satu bentuk keteraturan alam yang bisa kita rasakan dan teramati adalah keteraturan gerak harian matahari yang selalu terbit di ufuk timur dan tenggelam di ufuk barat, dimana perubahan posisi matahari yang berkelanjutan memberikan pemaparan sinar matahari dengan spektrum warna yang beraneka ragam.

Pada cuaca yang cerah, pergerakan semu harian matahari ini menampilkan fenomena yang luar bisa dan dapat dinikmati oleh siapapun yang memandang. Pada saat senja tiba, tidak lama dari terbenamnya matahari terkadang kita bisa melihat pemandangan langit yang cerah, yang disebut dengan istilah lembayung senja. Dalam Kamus Besar Bahasa Indonesia (2006) istilah lembayung merupakan sebuah kata benda yang mendefinisikan penggabungan dua warna yaitu kuning dan ungu atau disebut dengan warna jingga. Definisi ini menggambarakan kondisi perpaduan warna yang tampak pada langit senja akibat penghamburan radiasi sinar matahari.

Dalam pemikiran yang bersifat primitif, acap kali fenomena alam lembayung senja dikaitkan ataupun dijelaskan dengan berbagai mitos yang mengakar di masyarakat. Mitos yang saat ini berkembang berkaitan erat dengan berbagai kepercayaan dengan hal-hal yang bersifat gaib, cerita-cerita dewa yang tesampaikan secara turun-temurun, atau pun larangan-larangan yang disampaikan dari orang tua terdahulu kepada anak-anaknya dengan menggunakan istilah kata "pamall". (Rahman, et al., ...). Dengan berkembangnya ilmu pengetahuan dan pola pikir masyarakat yang semakin maju, mitos-mitos yang banyak mengakar kuat di masyarakat mulai mengalami degradasi. Semua kepercayaan, cerita, dan larangan-larangan yang sudah mengakar kuat di kalangan masyarakat mulai tergeser pemikiran-pemikiran baru yang sifatnya lebih logis dan dibuktikan dengan berbagai metode ilmiah.

Artikel ini bertujuan untuk memaparkan eksplanasi ilmiah tentang terjadinya lembayung senja. Penjelasan ini dikaitkan dengan penghamburan gelombang elektromagnetik yang diradiasikan matahari oleh lapisan atmosfer bumi, persepsi mata yang menangkap sinar tampak dengan frekuensi tertentu, dan panjang lintasan dari hasil penghamburan cahaya putih (polikromatik) menjadi monokromatik. 


\section{Metode}

Metode yang digunakan dalam pengumpulan data ini adalah metode (library research) melalui penelaahan berbagai sumber ilmiah dalam bentuk buku-buku, literatur-literatur, danartikelilmiahyang sesuai dengan kajian yang dibahas dalam artikel. Berbagai sumber lainnya yang diperoleh baik dari hasil penelitian dan atau percobaan disintesis menjadi satu kesatuan untuk memperkuat eksplanasi ilmiah dalam memaparkan informasi.

\section{Hasil dan Pembahasan}

\section{Sekilas Mitos}

Mitos dalam bahasa Indonesia merupakan kata serapan yang diambil dari bahasa Yunani, yaitu "mythos" yang berarti cerita dewata, dongeng terjadinya bumi dengan segala isinya, dan ceritakepercayaan pada dunia gaib. Wallek dan Werren (dalam Budianta,1995: 243),mendefinisikan mitos sebagai cerita-cerita anonim mengenai asal mula alamsemesta dan nasib serta tujuan hidup, penjelasan-penjelasan yang diberikan olehsuatu masyarakat kepada anak-anak mereka mengenai dunia, tingkah lakumanusia, citra alam dan tujuan hidup manusia.

Istilah mitos dapat dikaitkan dengan berbagai cerita lama yang berkembang pada masa lalu, atau boleh dikatakan bahwa mitos adalah cerita yang sudah usang. Chulsum (2006:466) mengartikan mitos sebagai cerita tentang pahlawandan dewa pada zaman dahulu yang dipercaya secara turun-temurun. Mitosmerupakan milik masyarakat yang bersifat anonim dalam arti tidak bisa ditelusurisiapa pencipta/pembuat/pencetusnya,sehingga mitos tersebut dianggap sebagaimilik komunal masyarakat setempat. Mitos berkembang di masyarakat dari mulutke mulut dan umumnya bersifat lisan.

Mitos juga dapat dikaitkan dengan berbagai penjelasan tentang terjadinya alamsemesta (cosmogony), terjadinya susunan para dewa; dunia dewata (pantheon),terjadinya manusia pertama dan tokoh pembawa kebudayaan (culture hero),terjadinya makanan pokok, seperti beras dan sebagainya, untuk pertama kali(Danadjaja, 1986:52). Dalam hal ini mitos dijadikan sebagai pedoman dan arah bagi masyarakatdalam menjalani kehidupan sehari-hari agar berlaku lebih bijaksana. Mitosmenjadikan masyarakat pengikutnya menjadi patuh dan taat terhadap ajaranajaranyang dianutnya, untuk menciptakan suatu kesadaran akan tingkah laku dankeselarasan dalam hidup bermasyarakat.

Lebih jauh Timoer (1983:11) mengkaitkan mitos dengan tahayul sebagai akibat ketidaktahuan manusia, tetapi bawah sadarnya memberitahukan tentang adanya sesuatu kekuatan yang menguasai dirinya serta lingkungannya. Bawah sadar ini yang menimbulkan hadirnya berbagai rekaan dalam pikiran, yang lambat laun berubah menjadi kepercayaan. Mitos biasanya disertai dengan rasa ketakjuban atau ketakutan yang melahirkan sikap pemujaan atau ultus. Sikap pemujaan yang demikian dilestarikan dalam bentuk upacara keagamaan secara periodik dan disampaikan dari mulut kemulut secara turun-temurun membentuk sebuah cerita rakyat yang disebut dengan folklore.

Simon (2006) menemukan bahwa di masyarakat mitos memiliki fungsi yang cukup kuat, diantaranya adalah; 1) Proses penyadaran akan kekuatan gaib. Mitos bukanlah sekedar informasi tentang kekuatakan gaib, tetapi merupakan suatu cara untuk mengantisipasi, mempelajari, dan berelasi dengan Tuhan. 2) Memberi garansi bagi kekinian. Mitos mempresentasikan berbagai peristiwa yang pernah ada dan mengandung saran serta anstisipasi bagi kekinian. 3) Mitos merentangkan cakrawala epistemologis dan ontologis tentang realitas. Mitos memberikan penggambaran tentang dunia, tentang asal mulanya, tetapi bukan ilmu sejarah modern.

\section{Mitos Lembayung Senja}

Lembayung senja merupakan fenomena alam yang sering terjadi dalam kehidupan kita sehari-hari. Namun fenomena ini memiliki sejumlah cerita mitos di beberapa daerah di Indonesia, diantaranya di tatar sunda dan Banjarmasin.

Di daerah tatar sunda istilah lembayung dikenal dengan istilah "layung", dimana fenomena alam yang terjadi ditandai dengan penampakan langit senja yang berwarna kemerahan menjelang atau sesaat setelah matahari terbenam. Pada saat lembayung ini muncul, para orang tua acap kali memanggil anaknya untuk segera masuk ke dalam rumah dengan alasan bahwa pada saat lembayung senja muncul maka pada saat tersebut banyak penyakit yang akan muncul. 
Hal serupa juga terjadi pada kultur masyarakat di daerah Banjarmasih Kalimantan Selatan. Fenomena lembayung senja memiliki sejumlah mitos yang dipercayai oleh masyarakat di daerah ini. Beberapa mitos lembayung senja yang merakyat di Banjar : 1) Pada saat muncul lembayung senja yang berwarna kuning menyala dikatakan bahwa pada saat itu banyak bergentayangan hantu yang jahat yang dapat mencelakakan manusia sehingga lembayung senja sering di sebut dengan istilah "sanjakuning, bahantu", artinya lembayung senja yang berhantu. 2) Pada saat muncul lembayung senja, masyarakat mempercayai akan datanganya malapetaka dalam bentuk penyakit yang disebut dengan penyakit sangga (penyakit kuning), akan adanya angin kencang yang merusak, dan kejadian berdarah dimana ada kejadian pembunuhan terhadap seseorang (Restudia, 2016). 3) Mitos lain dari lembayung senja diidentikan dengan berkeliarannya santet yang mencari mangsa.

Dengan adanya mitos yang beredar di masyarakat ini menimbulkan sejumlah larangan dan anjuran yang disampaikan oleh orang tua kepada anaknya, diantaranya 1) Tidak diperbolehkan keluar dan beraktivitas di luar rumah pada waktu sanja kuning ini, khusus nya untuk anak-anak. 2) Dilarang duduk di depan pintu dan beranda rumah 3) Tidak diperbolehkan memasak dengan menggunakan kompor, tetapi harus menggunakan kayu bakar. 4) Dianjurkan untuk berdo'a memohon perlindungan. 5) Marabun dupa atau membakar kemenyan. 5) Dilarang membunyikan dan memainka nalatmusik

\section{Lembayung Senja dalam Perspekstif Religi}

Lembayung senja yang terjadi dalam keseharian merupakan keteraturan alam yang sudah terabadikan dalam Al-Quran, tepatnya dalam Surah Al-Insyiqaaq ayat ke-16. Dalam penggalan ayat tersebut disampaikan bahwa Allah telah bersumpah ketika cahaya merah di waktu senja dan ketika pada waktu malam, bahwa sesungguhnya manusia akan melewati fase kehidupan. Fase tersebut berjalan ketika pembuahan sel telur oleh sperma hingga manusia tersebut meninggal dan dibangkitkan kembali. Surah tersebut mengutarakan terjadinya kiamat dan janji Allah kepada orang yang beriman ketika kiamat (Maulana, 2012).

Dalam perspektif islam pemunculan lembayung senja yang terjadi pada saat terbenamnya matahari menjadi landasan dalam perhitungan pergantian hari atau penanggalan. Sistem penanggalan dalam islam (tahun hijriyah) berbeda dengan sistem penanggalan tahun masehi. Sistem penanggalan islam diawali dengan dengan gema adzan Magrib sebagai permulaan sebuah hari, sedangkan penanggalan masehi dihitung sejak waktu melewati jam dua belas malam. Dalam kepercayaan Tao dijelaskan pula bahwa waktu lembayung senja merupakan fase penyempurnaan manusia dalam kehidupannya. Matahari yang hampir terbenam diibaratkan dengan manusia yang telah mengalami perjalanan panjang kehidupan. Senja diibaratkan sebagai manusia yang sudah berumur tua. Cahaya matahari ketika senja tidak akan seterang cahaya matahari ketika siang. Namun, saat-saat ketika senja merupakan saat-saat yang paling indah di bumi.

Begitu juga manusia. Ketika menginjak usia tua, kemampuan fisik mulai menurun. Tubuh tidak lagi sekuat dahulu, namun manusia haruslah memancarkan kebijaksanaannya, harus mampu memberikan kesejukan, serta mampu menunjukkan kematangan jiwanya sebagai manusia. Saat tua sudah bukan lagi terombang-ambing oleh keputusan yang labil. Sebab, menurut ajaran Tao, seseorang ketika masuk usia senjanya kurang bijaksana, susah menyesuaikan diri, dan masih tinggi sifat egonya, maka ia akan tersisihkan, merasa kesepian, dan hidupnya tidak akan bahagia.Masa usia tua merupakan usia persiapan menuju akhir kehidupan. Kepercayaan Tao mengajarkan bahwa ketika manusia sudah memaknai arti hidup, maka ia akan memperoleh ketenangan batin menjelang akhir hidupnya. Dan ketika jiwanya terlepas dari jasad, ia akan berganti rupa menjadi dewa-dewi sesuai dengan buah dari ajaran Tao yang telah sempurna.

Kepercayaan yang lain pun memfilosofikan sebagai puncak penyempurnaan hidup seorang manusia untuk berganti menuju dunia yang lain, yakni dunia akhirat tempat segalanya akan kekal. Penyempurnaan dalam istilah Buddha Mahayana dikenal dengan sebutan Zen atau Dhyana. Zen atau Dhyana mengajarkan fokus pada sikap meditasi untuk mencapai penerangan dan kesempurnaan jiwa. Meditasi ini mengajarkan manusia untuk memusatkan seluruh pikirannya tidak lagi bersifat dualistik, sebab penyempurnaan berarti tidak lagi memikirkan kefanaan, dalam hal ini adalah dunia. Penyempurnaan adalah satu, yakni Buddha itu sendiri.

\section{Eksplanasi Ilmiah}

Eksplanasi merupakan sebuah penjelasan yang menerangkan mengapa suatu fenomena terjadi (Firman, 2018). Setiap eksplanasi ini membutuhakan dua komponen utama yaitu 
eksplanan dan eksplanandum. Eksplanan merupakan perkara yang menjelaskan, sedangkan eksplanandum adalah perkara yang dijelaskan (Ladyman, 2002).

Untuk dapat menjelaskan sebuah fenomena dapat digunakan dua jenis eksplanasi, yaitu eksplanasi ilmiah dan non-ilmiah. Eksplanasi ilmiah merupakan penjelasan atau eksplanasi yang dikemukakan oleh para ilmuwan berdasarkan bukti-bukti empiris yang diperoleh melalui langkah-langkah ilmiah (Pupafis, 2013).

Manoia (1980) menjelaskann bahwa eksplanasi ilmiah dapat dikembangkan dengan dua model, yaitu model eksplanasi bercorak peluang (probabilitas) dan model eksplanasi deduktif (model eksplanasi Hempel-Oppenheim).Model eksplanasi bercorak peluang menggunakan peluang secara statistik dalam mengemukakan eksplanan. Jika hukum empirik yang bersifat statistik digunakan untuk menjelaskan peristiwa statistik, eksplanasi masih disebut eksplanasi deduktif, tetapi jika hukum statistik digunakan untuk menjelaskan peristiwa khusus maka eksplanasi tersebut merupakan eksplanasi Inductive Statistical (I-S).

Model eksplanasi Hempel-Oppenheim disebut juga dengan eksplanasi Deductive Nemological (DN) yang mempersyaratkan kondisi-kondisi logis sebagai berikut (Firman, 2018): 1) Setiap ekspalanan harus secara deduktif mengarah pada eksplanandum. 2) Deduksi harus menggunakan hukum. 3) Eksplanan-eksplananharusmempunyai konten empiris.

\section{Persepsi dan Fisiologi Warna}

Nugraha (2008: 34) mengatakan bahwa warna adalah kesan yang diperoleh mata dari cahaya yang dipantulkan oleh benda-benda yang dikenai cahaya tersebut.Selanjutnya, Laksono (1998: 42) mengemukakan bahwa warna merupakan bagian daricahaya yang diteruskan atau dipantulkan.Terdapat tiga unsur yang penting dari pengertian warna, yaitu benda, mata dan unsure cahaya.Secara umum, warna didefinisikan sebagai unsure cahaya yang dipantulkan oleh sebuah benda dan selanjutnya diintrepetasikan oleh mata berdasarkan cahaya yang mengenaibendatersebut.

Bagian mata yang berperan dalam menginterpretasikan warna menuju otak adalah bagian retina. Retina merupakan lembaran jaringan syaraf berlapis tipis dan semi transparan. Bagian retina yang paling berperan dalam mengidentifikasi warna adalah sel batang dan sel kerucut. Berdasarkan sensitivitasnya, sel kerucut dibagi menjadi tiga macam yaitu Scone, $\mathrm{M}$ cone, dan $\mathrm{L}$ cone, sedangkan sel batang hanya terdiri dari satu sel. Sel kerucut yang pertama cukup sensitive pada gelombang pendek (short wavelengths), yang kedua pada gelombang medium (medium wavelengths), yang ketiga pada gelombang yang panjang (long wavelengths).

Sensitivitas penglihatan warna normal tergantung dari spectrum cahaya yang lebihbanyakdiserapdariketigasistem (merahhijaubiru), perbedaanwarna yang terlihat tergantung dari tipe sel kerucut yang distimulasi. Ketika sel kerucut dirangsang oleh cahaya, sinyal tersebut akan ditransmisikan melalui neuron yang terkait melalui serat saraf optic menuju korteks serebradi bagian otak (Guyton \& Hall,1997).

Untuk dapat memahami bagaimana warna terbentuk para ilmuwan melakuan sejumlah percobaan. Newton mencoba menjelaskan persepsi warna pada mata dengan percobaandenganmelewatkancahaya putih matahari pada sebuh lubang kecil dan mengenai sebuh prisma. Ternyata cahaya putih matahari yang bagi kita tidak tampak berwarna, oleh prisma tersebut dipecahkan menjadi susunan cahaya berwarna yang tampak di mata sebagai cahaya merah, jingga, kuning, hijau, biru, nila, dan ungu, yang kemudian dikenal sebagai susunan spektrum dalam cahaya. Jika spektrum cahaya tersebut dikumpulkan dan diloloskan kembali melalui sebuah prisma, cahaya tersebut kembali menjadi cahaya putih.Jadi, cahaya putih sesungguhnya merupakan gabungan cahaya berwarna dalam spektrum.

Newton kemudian menyimpulkan bahwa benda-benda sama sekali tidak berwarna tanpa ada cahaya yang menyentuhnya. Sebuah benda tampak kuning karena fotoreseptor (penerima cahaya) pada mata manusia menangkap cahaya kuning yang dipantulkan oleh benda tersebut. Sebagai contoh sebuah apel tampak merah bukan karena apel tersebut berwarna merah, tetapi karena apel tersebut hanya memantulkan cahaya cerah dan menyerap warna cahaya lainnya dalam spektrum. Warna hitam pada benda dikarenakan benda tersebut menyerap semua unsur warna cahaya dalam spektrum dan tidak satu pun dipantulkan atau benda

Selanjutnya James Clerck Maxwell membuat serangkaian percobaan dengan menggunakan proyektor cahaya dan filter berwarna. Hasil eksperimen Maxwell menyimpulkan bahwa warna hijau, merah dan biru merupakan warna- warna primer dalam pencampuran warna cahaya. Warna primer adalah warna- warna yang tidak dapat dihasilkan lewat pencampuran warna apapun. Melalui warna-warna primer cahaya ini (biru, hijau, dan merah) semua warna cahaya dapat dibentuk dan diciptakan. Eksperimen Maxwell merupakan model 
atau tiruan yang bagus sekali untuk memudahkan pemahaman kita tentang bagaimana reseptor mata menangkap cahaya sehingga menimbulkan penglihatan berwarna di otak.

Secara fisiologi, warna yang teramati oleh mata merupakan bagian dari gelombang elektromagnetik dengan panjang gelombang dan frekuensi tertentu seperti yang ditunjukkan pada Gambar 1.

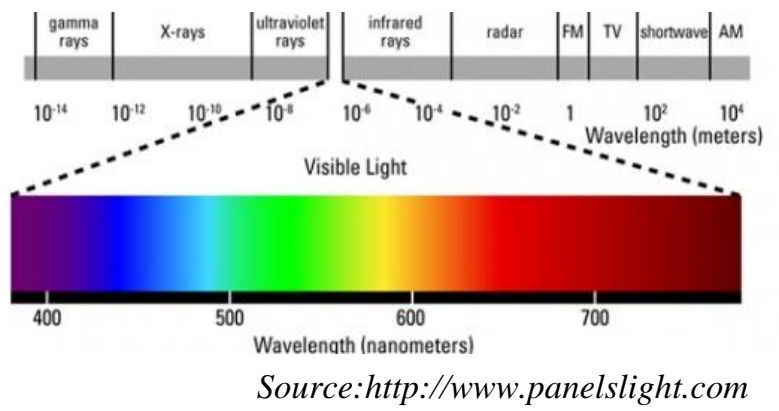

Gambar 1

Spektrum gelombang cahaya tampak

Dari Gambar 1 dapat kita lihat berbagai spektrumgelombang elektromagnetik berdasarkan panjang gelombang dengan panjang gelombang terendah berupa sinar gamma hingga gelombang AM (Amplitudo Modulation) dengan panjang gelombang tertinggi. Dari sederetan gelombang elektromagnetik, segmen yang paling pentingbagikehidupanadalah pita sempit yang panjanggelombangnyaberkisarantara $380 \mathrm{~nm}$ hingga $750 \mathrm{~nm}$. Radiasiinidikenalsebagaicahayatampakkarenaterdeteksiolehmatamanusiasebagaibermacammacamwarna.(Campbell, 1999:186).Adapun perbedaan panjang gelombang untuk setiap segmen warna dari gelombang cahaya tampak di tunjukkan pada Tabel 1

Tabel 1. Spektrum gelombang cahaya tampak (Handoko \& Fajariyanti,...)

\begin{tabular}{llc}
\hline No & Warna & Panjang gelombang $(\mathrm{nm})$ \\
\hline 1 & Merah & $625-740$ \\
\hline 2 & Jingga & $590-625$ \\
\hline 3 & Kuning & $565-590$ \\
\hline 4 & Hijau & $520-565$ \\
\hline 5 & Biru & $435-520$ \\
\hline 6 & Nila & $400-435$ \\
\hline 7 & Ungu & $380-400$ \\
\hline
\end{tabular}

\section{Ekplanasi IImiah Lembayung Senja}

Eksplanasi Ilmiah lembayung senja dapat diungkap dengan menggunakan model eksplanasi deduktif dimana eksplanan yang digunakan dalam menjelaskan fenomena dari lembayung senja merupakan hukum empiris yang telah terbukti secara fisika. Eksplanan yang dapat digunakan dalam mengungkap fenomena lembayung senja terdiri dari karakteristik cahaya dan teori hamburan Rayleigh.

Fenomena lembayung senja merupakan penghamburan cahaya putih yang diradiasikan matahari dengan media partikel atmosfer bumi. Cahaya putih merupakan cahaya polikromatik yang terbentuk dari berbagai spektrum warna monokromatik (Tipler \& Mosca, 2008). Bayong (2009) menyebutkan bahwa hamburan dari radiasi gelombang elektromanetik matahari oleh atmosfer bumi bergantung kepada dimaeter partikel-partikel atmosfer (D) dan juga panjang gelombang radiasi $(\lambda)$. Jika diameter partikel kurang dari panjang gelombangmaka terjadi hamburan Rayleigh $(\mathrm{H})$ yang besarnya berbanding terbalik dengan panjang gelombang pangkat empat seperti persamaan di bawah ini.

$$
\square=\frac{1}{\lambda^{4}}
$$

Fiegel (2013) menjelaskan bahwa dua molekul utama di udara, oksigen dan nitrogen, sangat kecil dibandingkan dengan panjang gelombang sinar matahari yang masuk yaitu sekitar seribu kali lebih kecil. Secara istimewa, partikel dari oksigen dan nitrogen tersebut akan 
menyebarkan panjang gelombang terpendek yaitu biru dan ungu sehingga pada siang hari yang cerah langit akan tampak biru. Tetapi saat matahari terbenam, cahaya mengambil jalur yang lebih panjang melalui atmosfer ke mata daripada saat siang hari sehingga sebagian besar warna biru telah menyebar jauh sebelum cahaya mencapai mata. Akibatnya, spektrum cahaya yang sampai pada mata adalah gelombang cahaya tampak dengan panjang gelombang terbesar dan nilai hamburan yang kecil. Spektrum cahaya tampak dengan panjang gelombang terbesar adalah merah dan jingga. Spektrum warna tersebut kemudian merambat masuk ke dalam mata (retina) dan direspon oleh sel kerucut sesuai dengan panjang gelombangnya untuk diinterpretasikan oleh otak. Proses penghamburan cahaya putih oleh partikel atmosfer bumi ditunjukkan pada Gambar 2.

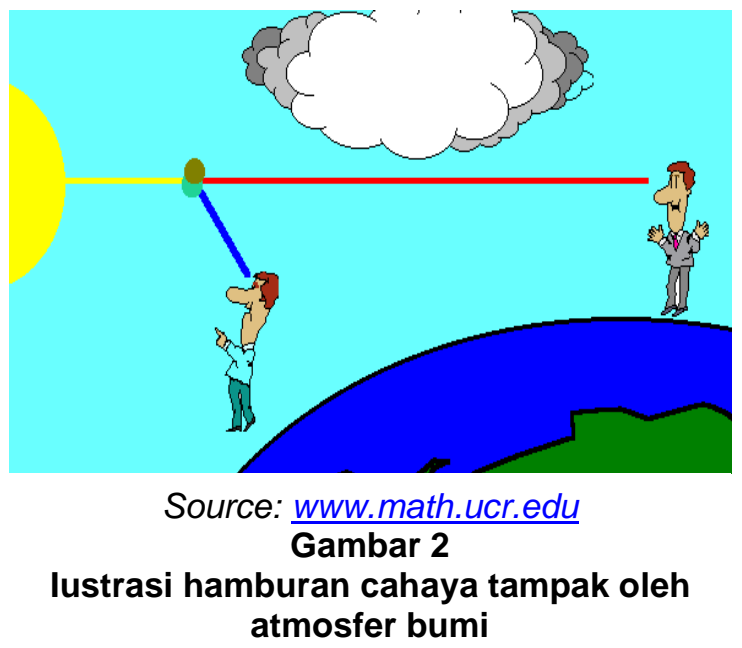

\section{Simpulan}

Lembayung senja sebagai fenomena alam yang lumrah terjadi pada saat cuaca cerah dapat dijelaskan dengan mitos-mitos yang berkembang di masyarakat maupun dengan eksplanasi ilmiah. Mitos-mitos yang muncul dari sebua fenomena alam merupakan sebuah kepercayaan yang menyebar secara lisan dan turun-termurun. Sedangkan eksplanasi ilmiah memaparkan sebuah fenomena dengan menggunakan hukum empiris yang telah dibuktikan secara ilmiah.

Mitos yang berkembang di masyarakat terkait lembayung senja dikaitkan dengan adanya hantu, santet, dan penyakit yang turun di waktu senja serta identik dengan adanya pembunuhan. Akibatnya muncul berbagai larangan yang diberikan orang tua kepada anaknya tanpa penjelasan logis seperti dilarang keluar rumah saat muncul lembayung senja, tidak memasak menggunakan kompor, dan tidak boleh memainkan alat musik.

Berbeda dengan mitos, eksplanasi ilmiah mencoba memberikan penjelasan yang bersifat logis terhadap fenomena lembayung senja dengan menggunakan model eksplanasi deduktif. Terjadinya lembayung senja terjadi akibat adanya hamburan cahaya putih yang diradiasikan matahari oleh partikel atmosfer bumi. Pada saat senja cahaya yang terhambur akan melewati jalur yang lebih jauh dari pada siang hari sehingga pada saat senja cahaya yang terhambur adalah cahaya dengan panjang gelombang yang besar yaitu warna merah dan jingga. Warna biru tidak muncul di waktu senja akibat telah terhambur pada daerah yang mengalami siang hari.

\section{Daftar Pustaka}

Budianta, Melani. (1995). Teori Kesusastraan (terjemahan dari penulis Wellek, Rene dan Warren, Austin). Jakarta: Gramedia

Campbell, (1999). Biologijilid I. Edisi V. Jakarta: Erlangga.

Chulsum, Umi, dan Windy Novia. (2006). KamusBesar Bahasa Indonesia. Surabaya: KashikoSurabaya

Danandjaja, James. (1986). Forklor Indonesia IImuGosipdanDongeng. Jakarta: Graffiti Press 
Fiegel, Amanda. (2013). Red Sky at Night: The Science of Sunsets. National Graphic News.

Firman, H. (2018). FilsafatSains. Program StudiPendidikan IPA. SekolahPascaSarjana UPI

Guyton A. C., Hall J. E. (1997). Buku Ajar FisiologiKedokteran.Edisi 9.Jakarta : EGC. P.

Handoko, Papib., dan Fajariyanti, Yunie. (....). Pengaruh Spektrum Cahaya Tampak Terhadap Laju Fotosintesis Tanaman Air Hydrilla Verticillata. Seminar Nasional X Pendidikan Biologi FKIP UNS.

Ladyman, J. (2002). Understanding Philophy of Science. London: Routledge.

Laksono, E., Wijayanti. (1998). Meramalkan zat pewarna dengan pendekatan partikel kotak 1 Dimensi. Cakrawala Pendidikan

Manoia, V. J. (1986). What is Science? : Introduction to the structure and methodology of science. Lenham, MD: University Press of America.

Maulana, Arief. (2012). Lembayung Senja dan Penyempurnaan Hidup.

Nugraha, Ali dan Rachmawati, Yeni.(2008). MetodePengembanganSosialEmosional. Jakarta: Universitas Terbuka

Pupafis. (2013). Ekspalanasi ilmiah dan eksplanasi pedagogis. Terdapathttp://momentumsudutdanrotasibendategar.blogspot.co.id

Rahman, Doni., Pratiwi, Yuni. Roekhan. (....). Kajian Mitos Masyarakat terhadap Forklor. Semarang: Tidak diterbitkan.

Timoer. (1983). Mitos Ura-Bhaya Cerita Rakyat Sebagai Sumber Penelitian Surabaya. Jakarta: Balai Pustaka

Simon, Fransiskus.(2006). Kebudayaan dan Waktu Senggang. Yogyakarta: Jalasutra.

Soenarto, Timoer. (1983). Mitos Ura-Bhaya Cerita Rakyat Sebagai Sumber Penelitian Surabaya. Jakarta: Balai Pustaka.

Tipler, Paul dan Mosca, Gene. (2007). Physics for Scientists And Engineering, with Modern Physics. New York: W. H. Freeaman and Company.

Tjasyono, Bayong. (2009). Ilmu Kebumian dan Antariksa. Jakarata: Remaja Rosdakarya dan Universitas Pendidikan Indonesia. 